\title{
Exploring Bicultural Experiences: Responding to a Chinese American Young Adult Novel
}

\section{SHWUYI LEU}

North Central College, Naperville, Illinois

\section{Introduction}

Culture is the terrain through which the individual speaks as a member of the contemporary national collectivity, but culture is also a mediation of history, the site through which the past returns and is remembered, however fragmented, imperfect, or disavowed. Through that remembering, that re-composition, new forms of subjectivity and community are thought and signified. (Lowe, 1996, p. x)

In remembering, creating, and re-imagining their forefathers' and their own American experience, Asian American i children's literature writers "reposition themselves as central to the American experience rather than peripheral" and create narratives "as an integral part of the multilayered tapestry of the 'American' experience'” (de Manuel \& Davis, 2006, p. vii). In reading and responding to Asian American children's literature, Asian American readers enter the terrain through which they connect to their ancestral and cultural traditions (Ching \& Pataray-Ching, 2006) and "find their place in the picture of the American cultural landscape" (de Manuel \& Davis, 2006, p. vii). The act of writing and reading Asian American children's literature is a part of what Lowe (as quoted above) indicated, i.e., forming and reforming their subjectivity. The reading of multicultural literature also provides opportunities for the rejection of stereotyped thinking (Farrell, 1990). Most importantly, it creates opportunities for members from parallel cultures to become aware of alternative thoughts, to value their own culture, and to enhance the development of a positive identity (Enciso, 1994; Sims, 1983; Spears-Bunton, 1990). Leung (2003) also contends that cross-cultural readings serve as positive supports for minority students' ethnic identity development as well as a pool of diverse culture learning opportunities for mainstream students.

A number of researchers (Applebee, 1978; Galda, 1980; Holland, 1975; Hyndes, 1985, 1989) have examined how adolescents and young readers respond to literature, but few researchers have investigated the comparative responses of different ethnic groups or of groups differentiated on the basis of geography or dialects. The current study sought to gain insights into this particular area. It investigated ways in which Asian/Asian American readers identified with fictional characters and cross-cultural experiences that are reflective of their own experiences. More specifically, the study focused on responses to cross-cultural experiences and the betweentwo-world situations (Ling, 1990). The between-two-worlds dilemma was first noted by Stonequist (1937) to describe the struggle of younger generations of Asian immigrants to survive at the interface between their ancestral culture and American culture. Because the mores of the two distinct cultures were so divergent, conflicts arose as the younger generation became Americanized. Although the current study focuses on adult and young adult readers, it has important implications for K-12 curriculum. It speaks to the importance of including culturally conscious books ${ }^{\mathrm{ii}}$ of parallel cultures in the K-12 curriculum and instructional practices that foster positive understandings of the self and others. I will first present related literature that informed and served as a framework for the study. Then the method of the study, results, discussion of results, and implications of the study will follow. 


\section{Cross-Cultural Text Reading and Ethnic Identity Development}

To understand how readers respond to literary work that mirrors their own experience, it is first necessary to consider the existing literature in reader response studies as well as ways in which cultural background and identity impacts responses to literature. In this section, I will first review the major factors bearing on responses to literature in general, and ethnic literature in particular. Next, the cross-cultural individual's identity development focusing on between-twoworlds situations is explored.

\section{Response to Literature}

Louise Rosenblatt's (1938/1983) groundbreaking work established that the process of responding to a literary work is not just a matter of retrieving information; rather, it is a transactional process between the reader and the text. Rosenblatt argued that what the readers bring with them to the act of reading is as important as the text itself. Furthermore, the process of literary response is not only a transaction between the reader and the text but also a lived-through experience by the reader. The transactional theory shifted researchers' focus from the text per se to a dynamic interaction among the texts, the readers, and the relevant contexts. It is through this view that theorists argue that not only do readers transform the text; they are also transformed by the text. Research in reader response studies consistently concludes that reader response is multidimensional and is a phenomenon influenced by the interplay of three major factors: characteristics of the reader, including personal attributes and culture, cognitive and social cognitive abilities, age, gender, and affective development (Galda, 1980; Holland, 1975; Hynds, 1985, 1989); textual factors (Galda, 1980, 1982); and the circumstances of the reading event (Beach, 1993; Purves, 1975; Purves \& Rippere, 1968). Holland (1975) found that readers respond to a literary work according to their own personalities and identities. Text became meaningful to the readers if they could identify with the characters and, by making the characters real, the readers satisfied certain needs and desires of their own.

The findings that (1) a reader's cultural background and identity play significant roles in how the text is read and (2) the text becomes more meaningful if the reader can identify with the characters have implications for readers from parallel cultures. Few studies have examined nonWhite readers' responses to literature. Sims (1983) studied the reading preferences of a ten-yearold girl who liked to read about strong, Black, female characters and stories that reflected her own culture, i.e., texts to which she could relate. Spears-Bunton (1990) observed that culturally conscious ethnic literature engaged students, both African American students and European American students. Using the case study approach, Leung (2003) worked with three Asian American students and one biracial (Jewish and Eastern European) student to explore factors involved in their reading of Jean Fritz's Homesick (1982). The researcher concluded that personality traits, genre knowledge, knowledge of Chinese culture, and stage of ethnic identity development were the major factors bearing on the differences of the four readers' responses. Leung's (2003) study specifically addressed the relationships between ethnic identity development and the readers' ability to interpret cross-cultural texts.

\section{The Between-two-worlds Dilemma}

Models of ethnic identity development have been proposed by a number of researchers in the fields of counseling psychology (Alvarez, 2002), sociology (Lien, Conway, \& Wong, 2003; Pyke \& Dang, 2003), and multicultural education (Banks, 1981). The current study traced the 
concept of the between-two-worlds dilemma to earlier studies and followed an identity-searching model based on the analysis of literary texts. Stonequist (1937) described the struggle of younger generations of Asian immigrants trapped between their ancestral culture and American culture as the between-two-worlds dilemma. In The Marginal Man, Stonequiest (1937) stated that "the dilemma of the second generation of immigrants, particularly Asian immigrants, was that s/he could not identify herself/himself completely with either civilization" (p. 105). In other words, they belonged neither to the United States nor to their Asian national roots. In the East, for example, traditional values emphasize family cohesion and harmony, patriarchal authority, and respect for ancestors/elders. In contrast, individualistic and egalitarian values are stressed in the United States.

Asian American children's experiences of growing up in mainstream culture make them culturally American, but racially Asian. Stonequiest (1937) noted that problems arose as a result of growing up with two distinct cultures:

The tension in the mind of the second generation is more pervasive and profound than appears on the surface. He is bound to his parents by the usual family sentiments. But his loyalty to them clashes with his loyalty to his friends and to the American culture which they symbolize. The ways of his friends stand for his future; the ways of his parents for his past. (p. 99)

The principal struggle that cross-cultural people face is that they are often compelled to choose one culture with which to identify. As they struggle to emerge and identify with the mainstream culture, their elders, viewing it from the standpoint of their traditional values, criticize them as showing lack of respect, good behavior, and interest in the ancestral culture (Stonequiest, 1937). They are torn between two cultures.

In addition to the identity confusion, younger generations of immigrants whose skin color and facial features are distinct from those of the mainstream groups, such as Asian American immigrants, still suffer from cultural and ethnic prejudice and even racism in modern American society (Cai, 1992; Ling, 1990; Takaki, 1998). While there is the rejection from the home culture, the outer world - the mainstream culture, does not accept them either. As Stonequist (1937) and other researchers (Cai, 1992; Takaki, 1998) noted, the second generation of Asian American immigrants would feel a certain amount of estrangement because they were considered and treated as Orientals but not Americans. It is even more difficult for the younger generation of Asian immigrants when they are the objects of racial prejudice and discrimination. For some, their efforts to assimilate aroused the anxiety and opposition of their parents and their lack of assimilation resulted in aversion of the mainstream people. They are caught between two worlds.

This between-two-worlds condition is more or less a fact of life for most nonmainstream, second-generation groups in the United States. In a study investigating acculturation, Child (1943) observed three types of reactions in second-generation Italians dealing with the cultural conflicts between their ancestral traditions and the mainstream American culture. The first type of solution in resolving the conflict is to become accepted by the American group, the so-called the rebel reaction. The second type of reaction is to maintain the loyalty and membership in the Italian group by rejecting the American culture. The third type of reaction is to avoid the conflict of neither denying the home culture nor the dominant culture.

The psychological suffering is greater for those whose physical features, such as skin color or facial features, are distinctly different from those of mainstream people (Stonequiest, 1937; Takaki, 1998). Ling (1990), a Chinese American woman writer, contended that "a minority individual's sense of alienation results not only from rejection by the dominant culture 
but also rejection of parental strictures" (p. 123). Minority parents' insistence on their children's acceptance of family traditions demonstrated their own fear of losing their cultural heritage. Even if the parents do not force their children to follow the traditions of their homeland, still "one cannot escape the between-worlds condition as a non-white in the United States" (Ling, 1990, p. 119). Because of this between-worlds dilemma, cross-cultural children experience "dual self-consciousness and identification" (Stonequist, 1937) and, very possibly, go through four stages of searching for identity, as suggested by Shannon ${ }^{\text {iii }}$ (1988). They go through these stages because they are raised with two ways of seeing in which each represents a different image of the self.

The first stage is the rejection by both of their conflicting cultures. In the second stage, they come to a situation in which they accept one culture while denying the other. During the third stage, they attempt to meld the conflicting cultures at the same time. In the final stage, they reach a status where they acknowledge and accept their own "individual and evolving identity as a collage of cultures" (Shannon, 1988, p. 14). The experience of going through different stages was also evidenced in Amy Ling's (1990) Between Worlds: Women Writers of Chinese Ancestry, and Laurence Yep's autobiography, The Lost Garden (1991a) and his three children's books: Child of the Owl (1977), The Star Fisher (1991b), and Thief of Hearts (1995).

Ling (1990), a Chinese-American writer, analyzed Chinese-American women writers' works and their backgrounds so that "the old stereotypes of demure lotus blossoms and treacherous dragon ladies" (p. 17) could be broken. Ling found not only that a between-worlds condition reflected in these Chinese-American women writers' works, but also that the descendants of Chinese who came as laborers to build the railroads were still seen as foreigners because of their facial features and skin color.

Laurence Yep (1991a), a Chinese American and children's book author, stated in his autobiography that "like many other Chinese children of the time, I thought of myself as American" (p. 41). As a child, he did not realize that he was different and even terrified his mother by imitating the squinted eyes of the Chinese laundrymen of a T.V. program. He stated that:

[i]t took me years to realize that I was Chinese whether I wanted to be or not...Or perhaps I should say I am a Chinese American rather than Chinese because I could never fit in China either. (p. 43)

Cross-cultural people have to learn to accept and understand the strengths and weaknesses of belonging to two cultures. As Yep (1991a) stated, "[I]t's something that is a part of me from the deepest level of my soul to my most common, everyday actions" (p. 43). The rejection of either one or both cultures will not bring them out of the between-worlds confusion. The searching of a personalized identity is a process of self-realization of this between-worlds dilemma (Shannon, 1988). It is through the process of forming an inclusive and personalized identity out of multiple cultures that they grow out of the confusion of being in and out of multiple cultures. This solution of out of the between-two-worlds dilemma is what Shannon (1988) described in the fourth stage of cross-cultural children's searching for identity. It is also what Yep (1989) had stated about the way in which he dealt with the struggle of being in two cultures, describing it as an effort to "juggle elements of both cultures."

The testimonies of cross-cultural writers and their works reflect the undeniable existence of the between-two-worlds conditions. It also seems clear that, in order to reach a comfortable acceptance of maintaining cross-cultural heritages, dual cultural people need to work through a process of establishing a unique cross-cultural identity consisting of parts from each culture. A 
review of relevant literature indicates that between-two-worlds situations are common for crosscultural individuals and that identity development plays a role in multicultural reader response.

\section{Methods}

\section{Participants}

The original study design planned on the recruitment of undergraduate students who were members of the Asian American Association, which was one of the student organizations at one large Midwestern American university. Because of the low number of participants subsequently recruited, Asian and Asian American graduate students at the College of Education and members of the Chinese Women Study Group were also invited to participate in the study. A total of 12 young adults and adults with Asian and Asian American ethnic background ultimately participated in the study. Their demographic features are summarized in Table 1.

Table 1: Participants' Demographic Information

\begin{tabular}{llcccl}
\hline $\begin{array}{l}\text { Name } \\
\text { (Pseudonyms) }\end{array}$ & Ethnic Background & Gender & Age & $\begin{array}{c}\text { Time of } \\
\text { (Family's) } \\
\text { Arrival }\end{array}$ & $\begin{array}{l}\text { Reason for } \\
\text { Coming to } \\
\text { the U.S. }\end{array}$ \\
\hline Lynn & $\begin{array}{l}\text { Biracial } \\
\text { (Chinese/White) }\end{array}$ & F & Under 20 & 1967 & Education \\
Everlyn & Chinese-American & F & Under 20 & 1973 & Immigration \\
Ivan & Chinese-American & $\mathrm{M}$ & $20-25$ & 1978 & Education \\
Alan & Chinese-American & $\mathrm{M}$ & $20-25$ & 1971 & Immigration \\
Amy & Brazilian-Chinese & $\mathrm{F}$ & Above 30 & 1981 & Education \\
Paul & Chinese-American & $\mathrm{M}$ & Above 30 & 1929 & Education \\
Jane & Chinese-American & $\mathrm{F}$ & Above 30 & 1920 's & Immigration \\
Jennifer & Korean-American & $\mathrm{F}$ & $26-30$ & 1981 & Immigration \\
Margaret & Korean-American & $\mathrm{F}$ & $20-25$ & 1983 & Immigration \\
Betsy & Korean-American & $\mathrm{F}$ & $20-25$ & 1980 & Religion \\
Lisa & Taiwanese & $\mathrm{F}$ & $26-30$ & 1993 & Education \\
Leah & Taiwanese & $\mathrm{F}$ & Above 30 & 1994 & Education \\
\hline
\end{tabular}

The twelve participants include a biracial Chinese and White female student, five Chinese Americans (three males and two females), three female Korean Americans, one female Brazilian Chinese American, and two female Taiwanese. Except for the two Taiwanese students and one Chinese American male student, nine of the twelve participants were second and third generation Asian Americans. The age of participants ranged from under twenty to above thirty years old. Having a variety of sources from which the participants were recruited and different age levels ultimately yielded interesting data and proved to be valuable for the study.

\section{Reading Material}

The Star Fisher by Laurence Yep (1991b) is about a Chinese American family moving from Ohio to a small West Virginia town in 1927. Through the eyes of a fifteen-year-old girl, Joan Lee, the struggle of being in between two cultures is presented. Although she was born in America, she was not considered American by the members of the mainstream culture. It is a story about finding oneself and a viable place in one's society. It is a culturally conscious book depicting the conflict between two cultures and how the second generation of an immigrant 
family struggles to survive between two different worlds. The text is appropriate for the present study for several reasons. First, Yep himself is a minority group member who grew up in a mainstream culture. His experience of cross-cultural conflicts is authentic. Second, as a winner of both the Christopher Award and the West Virginia Literary Award, the book has obvious literary merit. Thirdly, the story was based on the experiences of his family history. Finally, as stated in the "Author's Preface" of The Star Fisher, the story was not unique to his family; it was a story of many Chinese Americans.

\section{Procedures}

Participants were each given a copy of The Star Fisher and were asked to complete a questionnaire (Appendix A) anonymously. The questionnaire contained three parts. The first part obtained demographic information from the participants. The second part focused on participants' responses to the reading of the book relative to the protagonist's experience of being in two different cultures. The final section investigated their experience of reading multiethnic literature.

\section{Data Analysis}

Data collected from the questionnaires were analyzed based on the content of the responses (Glesne \& Peshkin, 1992). Content analysis is the process of "identifying, coding, and categorizing the primary patterns in the data" (Patton, 1990, p. 381). During the process of creating and transcribing the data, I repeatedly read the data to identify emerging patterns and themes that appeared to be significant. I began by creating personal profiles of the twelve participants; then, following the questions in the questionnaire, I categorized the data into (1) responses to racial discrimination depicted in the text, (2) responses to relationships with peers in the wider society, (3) responses to relationships with parents at home, (4) responses to the between-worlds issue, (5) responses to the main character with which they identify, and (6) responses regarding experiences in reading multiethnic literature. Shannon's (1988) model of cross-cultural identity development was then used to identify the participants' stage of development.

\section{Limitations of the Study}

One major limitation of the study was that, due to the design of the questionnaire, only short responses were elicited. If the design of the questions had been different, more extended responses could have been elicited. Secondly, the anonymous design restricted the obtainment of detailed information of each participant and the availability of carrying out a second level of investigation. The reason for using anonymous design was to ensure that the study was ethical with respect to protecting the participants' psychological wellbeing.

\section{Results and Discussion}

Several themes emerged as a result of the data analysis. First, the results of the study confirm previous research findings that readers' cultural background and personal experiences shape their understanding and interpretations of the text. Respondents related their cultural backgrounds and personal experiences to the reading, and made critical responses. Most of them also reflected on their status of being a minority group member in a mainstream society. Second, a particularly strong theme which emerged from the responses to this particular cross-cultural work was the experience of having to juggle between two cultures. Third, the results revealed 
that one of the 10 cross-cultural participants was in stage one as described by Shannon's (1988) cross-cultural identity development model, two appeared in stage two, three were in stage three, and two reached the final stage. Finally, the results indicated that Asian Americans continue to experience racism and are frequently viewed as non-Americans today as reflected in the responses of the Asian American participants.

The Basis of Response: Cultural Background and Personal Experience

The data clearly indicated that personal background and experience form the basis of participants' responses. As Purves and Rippere (1968) have explained, readers cannot approach the universe as portrayed in the work without recourse to the universe that s/he already knows. This was evidenced in the insiders' viewpoints of the participants who either grow up in the United States (U.S.) or are recent immigrants versus the outsider viewpoints of the two Taiwanese participants who just came to the U.S. for their graduate study.

When responding to a racial incident, those who responded from an insider's viewpoint gave comments such as "typical," "not unusual occurrence," "similar experience," "it happens a lot...a familiar feeling," and "something common to Asian American," which demonstrated that this kind of experience was not atypical. On the other hand, the two non-immigrants who just came for their graduate study were unable to relate to the protagonist's experience portrayed in the work. Therefore, they commented on the incident from an outsider's viewpoint and did not relate the incident to their personal experiences. For example, both of them responded to the content directly without making extended responses. One of them commented on the racial incident as "[S]tupid" because "[N]ot only do Americans 'talk American." The other one attempted to explain that Mr. Snuff "dared to call them 'Darn monkeys' since he assumed they couldn't speak the language." The insiders' and outsiders' reactions to the incident of racial discrimination supported the point that individual experiences shape his/her responses to a particular literary work (Petrosky, 1976; Purves \& Rippere, 1968).

Furthermore, the two Taiwanese graduate students had very different responses to the between-worlds situation as compared to those who had a longer stay or were born in the United States. Both of them claimed that they never had the same feeling as the protagonist had. Interestingly enough, one of them stated that "since the Star Fisher's daughter had never been to the sky, how strong feeling she got that she belonged to both the earth and the "the sky." The reader was clearly unable to identify with Joan's feelings of being in two worlds. The other reader claimed that "I just don't feel like this way." In contrast to their responses, the other ten participants who had shifted between two distinct cultures long enough, responded that they "often" or "sometimes" struggled with the between-worlds conflict. The distinction between insiders' and outsiders' responses to the between-worlds situation further indicates that cultural background and experience play important roles in the act of reading and responding to a literary work.

When cross-cultural people bring personal experiences to reading, they transact with text (Rosenblatt, 1938/1983). They are not just reading for the literal meaning or the meaning intended by the author. Instead they create meanings which are unique to them. This was the case with participants who critically analyzed their status of being a minority group member in a mainstream society. For instance, one Korean American participant commented that "[E]ven if we've been here for many generations, we still look foreign."

The shaping of an individual's worldview is complex. The data presented in this preliminary study provided insight into how cultural background and personal experiences shape and perhaps even limit an individual's understanding of texts/world. 


\section{Between Two-Worlds/Culture Struggle}

Researchers and bicultural writers have often described how cross-cultural children experience the between-world situation (Cai, 1992; Ling, 1990; Shannon, 1988; Stonequist, 1937; Yep, 1991a). The process of searching for identity is not an easy task for people with dual cultural heritages. As Shannon (1988) noted, "[B]orn between cultures, cross-cultural children become archetypal existential characters, for they must create themselves and establish their own meaning out of a confusing and antagonistic world" (p. 18). The results demonstrated that most participants experienced the feeling of belonging to neither world and/or the cultural conflicts between the home and the mainstream society, especially those who were born in the United States or were recent immigrants.

Cross-cultural people who sense two different worlds feel alienated. On the one hand, s/he is discriminated against because of his/her ethnic background, as Joan is in school and society. Yet, on the other hand, because she is also American, she feels alienation from her ancestral culture. Six participants specifically commented on the between-two-worlds situation. Lynn $^{\text {iv }}$, a Chinese and White American, reported that she felt "very much" like being inbetween-worlds situations given that she was "not entirely White yet not entirely Asian." Ivan, a Chinese American, stated that "I certainly identify with [Joan's]... feelings of alienation from her peers and her feeling caught between two worlds." Jane, another Chinese American, described her struggle with the two worlds as "[T]rying to explain Chinese "ways' to Caucasian friends and trying to explain 'American' ways to Chinese friends." Betsy, a Korean American participant, noted that she experienced confusion before but had grown out of it:

I understand her resentment towards her mom for making her do all the dirty work because of mom's lack of English. Joan struggles to fit in. Everybody struggles with that one. Joan knows how it feels to be alienated so she tries not to do that with Bernice. I try to do that also. I, personally, don't struggle too much with trying to figure out the best possible method or route. I just do or say what comes to me and be as honest as possible. Betsy admitted that it was a struggle for her and resented the fact that her mother made her do all the "dirty work." She, however, was able to rise above it and be empathetic towards people that were in similar situation. She interpreted Joan's behavior toward Bernice through her experience in the past. This is consistent with what researchers have discovered that readers' experience and personality affect the ways in which they respond to texts (Applebee, 1978; Holland, 1975; \& Rosenblatt, 1938/1983).

Oftentimes, parents of an immigrant family, who disagree with the values of the dominant culture, impose stern strictures on their children. For example, in the story, Mrs. Lee insists that her children speak Chinese to each other in public and eat lunch separately at school. This further alienates her children from the other children. Margaret's statements indirectly supported this viewpoint even though she did not mention what kind of traditional values had been imposed upon her by her parents.

I would identify with Joan because I also have to translate for my mother at times. Since my parents feel so strongly about preserving one's own culture and tradition, they don't accept some of the 'American' way of life.

Because of the cultural difference between home and the wider society, bicultural people have to deal with two different sets of cultural values. Conflicts/tensions arise when the two sets of cultural values collide with each other and, especially when elders insist on preserving their ancestral traditions. 
Participants' responses clearly indicated that they were aware of the different values in the two cultures. Jennifer considered that "[I]t's a struggle to balance the Asian and American cultures (Education, goals, marriage, dating, etc.)." Other participants noted the differences, but did not specifically state that it was a struggle. Examples were given below:

Lynn: "I see it a lot with some of the things my mom believes about dating and studying. I have entirely different views."

Alan: "There is a big difference with personal freedom and family duties. Parental pressure also plays an important part with this."

Jane: "Social obligations; taking gift every time you visit someone."

Margaret: "My parents are pretty traditional Koreans. So, they do not fully accept the American culture."

Although tensions/conflicts were not specifically stated, the responses indicated different value systems between the generations. Betsy, a Korean American participant, seemed to figure out a way to deal with two sets of value systems:

It is easy to learn to shift gears and fit in to your surroundings. Sometimes it's just easier and becomes neutral. But having two cultural values gives one the option to choose the best out of the two and combine them. They don't necessarily have to collide with one another in a negative way.

American society is basically an immigrant society and a good number of young people have to deal with having two cultures. It is important that there is some way within the schooling system to assist young people in dealing with two cultures.

\section{Stages of Dealing with the Between-Worlds Dilemma}

Children who grow up between cultures are raised with two ways of seeing, and each provides a different image of the self. This "dual self-consciousness and identification" (Stonequist, 1937) may result in experiences in the four stages of searching for identity (Shannon, 1988): double outsiders, one versus the other, attempting to be both, and a unique, personalized identity. The process of identity development is complex and has no clear-cut boundaries. How participants progressed through the stages is beyond the scope of this study and could not be traced specifically using the data obtained. However, participants' responses indicated the stages they were at the time of study. Explanations of each stage based on Shannon's (1988) study and examples of responses that indicated stages of development will follow.

Stage 1: Double outsiders. In the beginning stage, cross-cultural people are double outsiders. Their acceptance of one culture is the denial of the other half of themselves. But, the question is also which half of themselves should they choose. Amy is such an example. She is an older Brazilian born Chinese who immigrated to America, who commented:

Not only is difficult to be from east/west cultural background I found that immigrant families are rather dysfunctional. The lack of support, nurturance and understanding made life even more difficult.

Amy seemed to be identifying herself with neither culture and chose to focus on the difficulties and frustrations of being an immigrant in general. Even though she is much older, she remained at the first stage where she seemed to view herself as double outsiders, i.e., receiving no support from either culture. 
Stage 2: One versus the other. The second stage is where the individuals choose one culture and deny the other. However, the choice is based on the outsider's need to categorize and separate things. They may feel lost and less than whole with either choice.

Alan (Chinese American) and Margaret (Korean American) were apparently still in the second stage because they appeared to choose one culture - the dominant culture as their identity. Alan noted that he became 'conspicuous' when he was with a larger group of Asians. Further, he stated that being athletically inclined, he was able to break barriers and blend into the mainstream culture instead of being a foreign person. In responding to how they identified with the main character in the book, he stated that:

I felt in agreement with sports being able to break barriers. Being athletically inclined, I became a student that is athletic, in essence an athlete, that others could relate to instead of a foreign person.

These statements seem to imply that his ethnic background made him a 'foreign person' and that there were barriers for him as an Asian American to mingle into the mainstream culture. There is a possibility that Alan is responding to the pressure of being athletically inclined for the male gender in the United States. As for Margaret, she did not have any remark that was a clear indication of her choosing a specific culture to identify with. She only stated that she got "frustrated" when she and her parents "argue[d] about certain American cultures." Obviously she identified with certain American cultures/values because she defended them.

Stage 3: Attempting to be both. At the third stage, with the feeling of less than whole, the cross-cultural individuals attempt to have double identities. In the case of Everlyn (Chinese American), Lynn (Chinese and White American), and Jennifer (Korean American), they were coming close to the end of the third stage where the choice of either culture made them feel lost and less than whole, thus they tried to have double identities. Everlyn and Jennifer stated that they sometimes still felt the alienation and were not sure to which world they belonged. Lynn attempted to see things through both cultures at the same time, but it was not always easy, as she stated.

Everlyn: "Conflicts. Not sure which you belong to, but glad that you have a bit of both." Jennifer: "Sometimes I felt like double alienated but there are times that I think [it] is beneficial to be culturally aware in two cultures."

Lynn: "Sometimes I see things from a Chinese view but at the same time my 'American' view and it is not always easy to decide which to follow."

Even though Everlyn and Jennifer were not yet quite out of the confusion, the recognition that having two cultures was more beneficial started to illuminate in them. They both noted that they were glad that they had two cultures. In other words, they began entering the final stage.

However, they would not feel at ease until a harmonized and unique collage of the two cultures of their own is created.

In looking at Betsy's and Jennifer's responses, age is not a prominent factor in the advancement of stages. Betsy was in her early twenties and had reached a comfortable stage of her racial/ethnic identity whereas Jennifer was in her late twenties and continued to struggle with a unified identity. What exactly had contributed to the two individuals' racial/ethnic identity development need further investigation. However, experiences that Betsy self-reported that made her more comfortable about who she was, were reading Korean children's books from early on and traveling back and forth between Korea and America. Jennifer did not report having the same type of experiences while growing up. 
Stage 4: Achieving unique, personalized identity. The last stage is when the individuals achieve their own personalized identity-a self-created identity. That is, a collage of multiple cultures. Betsy, a twenty-one-year-old Korean American, and Ivan, a Chinese American, had reached the final stage where they achieved their own personalized identity out of two cultures. Both declared that they experienced confusion before but that they grew beyond this state. Participants' responses also indicated that they had come to the realization that having multiple cultures was more beneficial than having a mono-cultural perspective. As Betsy stated, "I am thankful for my Korean and my 'American' heritage." Ivan also noted that, "I'm grateful for having the "double pair of eyes." In other words, participants created their own personalized identity - a unified Korean and American collage. The world that evolved for Betsy is a unique one which is neither Korean nor American, but a mixture of both. As she stated:

I'm not in both, I'm in the Korean-American world. They have mixed into one and I feel uncomfortable if either one was left out because that would mean that I would have to change drastically.

People who grow up with more than one cultural background, very possibly, go through this process of self-realization of dealing with multiple cultures. Achieving a self-created, unified collage of multiple cultures is necessary for a healthy psychological development and social well-being because such a status would allow them to understand who they are and help them to find a viable place in the society. More research is needed to understand ways in which crosscultural people attain this stage.

\section{Perpetuated "Foreigners"}

The Chinese have been in North America for over 140 years, but even today they are still seen as foreigners and newcomers (Cai, 1992; Takaki, 1993). Their physical features-the shape of their eyes (except surgically), the color of their hair (except by hair color dye), and the complexion of their skins - in part, resulted in this perpetuated foreigner status. In other words, younger generations still suffer from cultural and ethnic prejudice and even racism in the modern American society. The findings of this study support this as evidenced in participants' responses. Three participants commented that their ethnic background, especially the physical appearance, made them 'foreigners' regardless the fact that they were born and grew up in the U.S. "No matter how long you live in America, even if you were born here, you can't stop looking Asian' was made by one Korean American participant. Further, participants who were either Americanborn or recent immigrants, regardless of their age, all had similar experiences with racial discrimination due largely to their non-white ethnicity.

Another piece of evidence of being denied entry into American mainstream culture is how mainstream Americans react to Asian/Asian American's ability in speaking the English language. As Ling (1990) stated, "when American-born Chinese Americans, from families many generations in the U. S., are asked where they learned such good English, they too are made to feel foreign and alien" (p. 105). Seven out of the ten participants who either grew up in the U.S. or were recent immigrants responded that, receiving surprise faces from mainstream Americans at their English language ability was not an unusual occurrence for Asian Americans. Three participants noted that they had similar experience. The fact that all three of them were under twenty-five years supports Takaki's (1998) claim that descendants of Asian immigrants are not viewed as Americans in the modern American society.

Evelyn, a less than twenty-year-old Chinese American commented that "most 40-ish yrold Asians are immigrants, most have heavy accents," and that "I'm always surprised when I 
meet a 40-yr-old who speaks perfect English." These comments clearly reflect the mainstream racist and stereotypical view of Asian Americans. It is very possible that she is not aware of the history of Asian Americans and adopted mainstream views about Asian Americans. If the latter is true, she identified herself more with the mainstream culture than her Chinese American background and was unaware of her mainstream perspective.

It is not an easy task for people to see the culture in which they live for a long time. If they have not had the experience of being in different cultural environments or have had the opportunity to examine the differences between different cultures, it is difficult for them to see how some of the differences may affect their thinking as well as their behavior. The reading of this particular literary text provided an opportunity for the participants to reflect on their thinking of being a parallel cultural group member in the society.

\section{Concluding Thoughts and Implications}

This study originated from a personal experience of conflicts that stemmed from two distinctive cultures in contact. It also stems from the appreciation and comfort obtained from reading a children's book dealing with similar topics. The United States is a multiethnic society and the great number of immigrant children within it cannot be overlooked. Educators and researchers recognize that having a diverse student population is an issue for teaching and learning; however, not many recognize the fact that immigrant children need supports because of the between-two-world situations. A primary implication of the study is for educators to recognize the advantage of using multicultural/multiethnic literature in classrooms, especially the P-12 settings where many educators lack a knowledge base in this area.

Twelve Asian and Asian Americans were asked to read a children's book and anonymously respond to a three-part questionnaire. All the participants expressed positive remarks towards the reading of the book and the Asian American participants noted that it would have been helpful if they could read books of this type while they were growing up. Participants who were born in the United States and were recent immigrants related to and reflected on their experiences of being an Asian American in the United States. The findings suggested that cultural background and experience shape each individual's interpretation of texts and experiences, instead of age, influence the development of cross-cultural competence. The results also supported researchers' and writers' (Cai, 1992; Ling, 1990; Shannon, 1988; Stonequist, 1937; Yep, 1991a) view of the between worlds condition in cross-cultural people and stages of racial/ethnic identity development relative to dealing with the condition. Further, the findings add to the database of ethnic reader response on multicultural children's literature, which is quite scarce.

The study has important implications for educators at all levels and for future research. The need to include Asian American literary texts in K-12 is not a new notion. However, it continues to be a non-reality for students going through the system. My experience with many inservice teachers is that they are not aware of quality Asian American children's and young adult literature. More often, the inservice as well as preservice teachers resist the idea of multicultural literature and desired token books only. It is critical that educators in the teacher training programs are advocates for the inclusion of quality multiethnic literature. Most importantly, they must teach critical reading of the texts in order to foster in-depth understanding of the other. The study also has implications for future research. Do the between-two-worlds situations continue to exist for the third generations and on? How does the reading of multicultural literature influence the identity development of young people from parallel cultures 
in K-12 settings? Are teachers in the K-12 setting using multicultural literature? If so, how are they using it? Are they using more traditional literature rather than realistic narratives? There are many unanswered questions require further investigation.

Quality reading of multiethnic texts can foster rejection of stereotyping of people who are marginalized for all readers. It also provides mirrors for readers from the parallel cultures to understand the American cultural landscape and see themselves represented in the books they read. In other words, the process of responding to the text may make readers become more aware of who they are and contribute to positive racial/ethnic identity development. Through the reading of multicultural children's literature, teachers can help students understand the cultural conflicts that result from differences in beliefs, values, religion, and so forth, and assist students identify with the authors or the characters in the stories to reinforce students' positive self identity (Chi, 1993). To conclude, multicultural literature, especially cross-cultural literary work, not only sheds light on the life of the people and cultures but also acts as a medium of understanding people with dual cultural heritages.

Notes:

i A general definition of Asian Pacific Americans is that they are people who call the United States their home and who trace their ancestry to countries from the Asian continent and subcontinent and islands in the Pacific Rim (Hune, 1997). For the purpose of this paper, the term "Asian American" is used and Asian Americans refer to Americans whose national origins are included within the geographical triangle formed by Japan, Indonesia, and Pakistan (Lim \& Ling, 1992).

ii Culturally conscious books" is a term defined by Sims (1982) as books that "reflect, with varying degrees of success, the social and cultural traditions associated with growing up Black in the United States" (p. 49). The definition is used for the current study and refers to books about Asian Americans that were written from insiders' perspective.

iii Shannon analyzed young people in cross-cultural fiction, and found that, in the process of searching for identities, cross-cultural children seemed to go through four stages.

iv All the names of the participants are pseudonyms.

References

Alvarez, A. N. (2002). Racial identity and Asian Americans: Supports and challenges. New Directions for Student Services, 97, 33-43.

Applebee, A. N. (1978). A child's concept of story: ages two to seventeen. Chicago: The University of Chicago press.

Banks, J. A. (1981). Stages of ethnicity: Implications for curriculum reform. In J. A. Banks, Multiehnic education: Theory and Practice (pp. 129-139). Boston: Allyn \& Bacon.

Beach, R. (1993). A teacher's introduction to reader-response theories. Urbana, IL: national Council of Teachers of English.

Cai, M. (1992). A balanced view of acculturation: Comments on Lawrence Yep's three novels. Children's Literature in Education, 23, 107-118.

Chi, M. (1993). Asserting Asian-American children's self and cultural identity through AsianAmerican children's literature. Social Studies Review, 32, 50-55.

Child, I. L. (1943). Italian or American? The second generation conflict. New Haven, CT: Yale University Press.

Ching, S. H. D., \& Pataray-Ching, J. (2002). Memory as Travel in Asian American Children's Literature: Bridging Home and School. New Advocate, 15(1), 23-34. 
De Manuel D., \& Davis, R. G. (2006). Editors' introduction: Critical perspectives on Asian American children's literature. The Lion and the Unicorn, 30(2), v-xv.

Enciso, P. E. (1994). Cultural identity and response to literature: Running lessons from Maniac Magee. Language Arts, 71, 524-533.

Farrell, E. J. (1990). Introduction: Fifty years of Literature as Exploration. In E. J. Farrell, and J. R. Squire (Eds.), Transactions with literature: A fifty-year perspective (pp. ix-xiii). Urbana, IL: National Council of Teachers of English.

Fritz, J. (1982). Homesick: My own story. New York: Dell.

Galda, S. L. (1980). Three children reading stories: Response to literature in preadolescent. Doctoral dissertation, New York University.

---------. (1982). Assuming the spectator stance: An examination of the responses of three young readers. Research in the Teaching of English, 16, 1-20.

Glesne, C., \& Peshkin, A. (1992). Becoming qualitative researchers: An introduction. New York: Longman.

Holland, N. N. (1975). Five readers reading. New Heaven, MA: Yale University Press.

Hynds, S. D. (1985). Interpersonal cognitive complexity and the literary response processes of adolescent readers. Research in the Teaching of English, 19, 386-402. (1989). Bringing life to literature and literature to life: Social constructs and contexts of four adolescent readers. Research in the Teaching of English, 23, 30-61.

Lien, P., Conway, M. M., \& Wong, J. (2003). The contours and sources of ethnic identity choices among Asian Americans. Social Science Quarterly, 84(2), 461-481.

Leung, C. (2003). Bicultural perspectives and reader response: Four American readers respond to Jean Fritz's Homesick. Canadian Modern Language Review, 60(1), 27-54.

Ling, A. (1990). Focus on America: Seeking a self and a place. Between worlds: Women writers of Chinese Ancestry (pp. 104-157). Elmsford, NY: Pergamon Press, Inc.

Lowe, L. (1996). Immigrant acts: On Asian American cultural politics. Durham and London: Duke University Press.

Patton, M. Q. (1990). Qualitative evaluation and research methods (2nd Ed.). Newbury Park, CA: Sage.

Petrosky, A. R. (1976). The effects of reality perception and fantasy on response to literature: Two case studies. Research in the Teaching of English, 10(3), 239-258.

Purves, A. C. (1975). Research in the teaching of literature. Elementary English, 22, 463-466.

Purves, A. C., \& Rippere, A. (1968). Elements of writing about a literary work: A study of response to literature. Urbana, IL: National Council of Teachers of English.

Pyke, K., \& Dang, T. (2003). "FOB" and "Whitewashed": Identity and internalized racism among second generation Asian Americans. Qualitative Sociology, 26(2), 147-172.

Rosenblatt, L. M. (1983/1938). Literature as Exploration (4th ed.). New York: The Modern Language Association of America.

Shannon, George. (1988). Making a home of one's own: The young in cross-cultural fiction. English Journal, 77(5), 14-19.

Sims, R. (1983). Strong black girls: A ten year old responds to fiction about Afro-Americans. Journal of Research and Development in Education, 16, 21-28.

Spears-Bunton, L. A. (1990). Welcome to my house: African American and European American students' responses to Virginia Hamilton's House of Dies Drear. Journal of Negro Education, 59(4), 566-576. 
Stonequiest, E. V. (1937). The cultural hybrid (continued). The Marginal Man (pp. 83-119). New York: Charles Scribner's Sons.

Takaki, R. (1998). Strangers from a different shore $\left(2^{\text {nd }} E d\right.$.). Boston: Little, Brown and Company.

Yep, L. (1977). Child of the owl. New York: HarperTrophy.

------. (1989). The green cord. The Horn Book Magazine, 65, 176-178.

------. (1991a). The lost garden. New York: Julian Messner.

-----. (1991b). The star fisher. New York: Puffin Books.

-----. (1995). Thief of hearts. New York: HarperCollins Publishers.

Dr. Shwuyi Leu is an Associate Professor in the Education Department at North Central College in Naperville, Illinois. She earned her Ph.D. in Language and Literacy Education from the University of Illinois at Urbana-Champaign and her primary teaching responsibilities are in reading and literacy at both undergraduate and graduate levels. 
Appendix A

Survey of Reader Response to Laurence Yep's The Star Fisher

\section{$\underline{\text { Part } 1}$}

(1) Ethnic Background:

(2) I/My family came to the U.S. in for reason and I am the

(3) I grew up in a generation. African American, etc.).

(4) Gender: Male Female

(5) Age: Under 20 20-25 $25-30$ Above 30

(6) Field of Study:

(7) How would you categorize your family

(8) Level of education: Father neighborhood (e.g. White middle class, Asian American,

\section{$\underline{\text { Part } 2}$}

(9) What's your reaction to the scene when the Lee Family stepped out the train station and ran across with this hostile American who called them "Darn monkeys" and "Chinky" in the later part of the story? (p. $7 \&$ p. 133) [circle please]

$\begin{array}{lll}\text { Hate } \quad \text { Dislike } & \begin{array}{c}\text { Disagree } \\ \text { (please indicate) }\end{array} & \text { Don't care } \\ \text { Other kind _ } & \end{array}$

(10) Have you had any similar experience? Yes No

(11) What's your reaction to Mr. Lee's attitude--"just ignore him. (p. 7)--towards Mr. Snuff who called them "Darn monkeys".

The father is right. Disagree Don't care

If you disagree, please indicate what you think is "right" attitude:

(12) What's your reaction to Mr. Snuff's shock when he heard that Joan and Emily "talk American?" (p. 8) (Please circle all your responses.)

(a) Mr. Snuff is ignorant.

(b) Mr. Snuff thinks they are "foreigners" instead of Americans.

(c) Angry

(d) Other (please indicate).

(13) What kind of reaction did you receive when people hear you speak English and how did you respond to that? 
(a) surprised disliked don't care

(b) Your responses:

(14) "Even though we had been born here and could name all the presidents and the capitals of the states, there were so many little things that we didn't know--like place settings. In some ways, we were often like actors who were thrust on stage without a script, so that we had to improvise." (p.19)

To what extent this is true for you? Never Sometimes Often

Please explain:

(15) How do you react to Joan's experience with her parents when oftentimes she had to deal with two different sets of cultural values--at home and the outside world? (e.g. p.48)

Terrible Okay Sympathetic Don't care

To what extent this is true for you? Never Sometimes Often Please explain:

(16) How do you react to Joan's experience with her American classmates in which she often had a sense of being different and alienated? (e.g., p. 63)

Terrible Okay sympathetic Don't care

To what extent this is true for you? Never Sometimes Often Please explain:

(17) "And suddenly I knew how the star fisher's daughter must have felt: belonging to both the earth and the sky, she must have seen everything through a double pair of eyes. And I wondered if she felt just as angry and mixed-up inside as I did." (p. 72)

To what extent this is true for you? Never Sometimes Often 
Please explain:

(18) Do you think that the way Americans, except for Miss Lucy, perceive Asians/Asian Americans in the book is accurate?

Yes Part No

Please state your opinion of how Americans perceive Asian/Asian Americans in general:

(19) To what extent you feel like the Star Fisher's daughter's "being caught in two worlds"?

Very much so

1 2

3

Not at all

4

Please give a short description if this is not at all true for you:

(20) Discuss the ways in which you identify yourself with the main character--Joan, or other characters.

(21) What's your overall reaction to the book?

\section{$\underline{\text { Part } 3}$}

(22) Do you remember reading any children's books that featured "your group?" 
Yes No If yes, please respond to further questions.

Did the reading of this type of books affect you in any way?

(23) Do you remember reading multicultural children's books in school?

Yes No If yes, please respond to further questions.

How was the experience affect the children? Negative Positive Others (please indicate):

Did it affect you in any way? 